Türk Turizm Araştırmaları Dergisi
2020,4(1): 100-120.

\title{
Destinasyon Markası Oluşumunda Gastronomik Kimlik ve İmaj: Konya Örneği*
}

Dr. Öğr. Üyesi Burcu Ayşenur AKBULUT, Recep Tayyip Erdoğan Üniversitesi, Ardeşen Turizm Fakültesi, Rize, e-posta: burcuaysenur.akbulut@erdogan.edu.tr ORCID: https://orcid.org/0000-0002-0679-3692

Prof. Dr. İrfan YAZICIOĞLU, Ankara Hacı Bayram Veli Üniversitesi, Turizm Fakültesi, Ankara, e-posta: irfanyaz@gazi.edu.tr ORCID: https://orcid.org/0000-0002-8575-0817

\section{Öz}

Mevcut pazarın dinamikleri, turistlerin istek ve arzularının değişimi, destinasyonların sürdürülebilir bir rekabet üstünlüğü sağlayabilmeleri gibi nedenler destinasyonların taklit edilemez marka unsurlarının belirlenmesi zorunluluğunu doğurmuştur. Belirli yiyecek ve içeceklerle belirli bölgelerin eşleştirilmesi bölgeye özgü bir gastronomik kimlik ve imajın yaratılmasına olanak sağlamaktadır. Gastronomik kimlik ve imaj, her bir destinasyonda farklılık göstermekte ve bu farkl1lıklar o destinasyonun taklit edilmesi zor, özgün ve simgesel bir unsuru olarak yer edinmektedir. $\mathrm{Bu}$ araştırmanın temel amacı destinasyon marka oluşumunda gastronomik kimlik ve imaj unsurlarının belirlenmesidir. Araştırmada, duygusal gastronomik imaj, bilişsel/algısal gastronomik imaj, genel gastronomik imaj arasındaki ilişki ve genel gastronomik imajın genel destinasyon imajını etkileme düzeyi belirlenmesi amacıyla gastronomik imaj modeli oluşturulmuştur. Bu kapsamda araştırmada nicel veri toplama yöntemleri kullanılmıştır. Veri toplama araçları olarak gastronomik imaj ölçeği anketi ve yapılandırılmış soru formları kullanılmıştır. Bu araştırmanın evrenini Konya ilini 3 Aralık 2017- 15 Ağustos 2018 tarihleri arasında ziyaret eden turistler oluşturmaktadır. Örneklem grubunun seçiminde kolayda örneklem yöntemi kullanılmış ve 404 turiste ulaşılmıştır. Toplanan veriler yapısal eşitlik modeli testleri, Anova ve $t$ testleri kullanılarak analiz edilmiştir. Yapılan analizler sonucunda; genel gastronomik imajin destinasyon imajını yüksek düzeyde etkilediği, duygusal imajın bilişsel/algısal imajı ve genel gastronomik imajı yüksek düzeyde etkilediği, bilişsel/algısal gastronomik imajın da genel gastronomik imajı orta düzeyde etkilediği belirlenmiştir. Ayrıca araştırmada, Konya'nın gastronomik marka algısına verilen cevaplarda en yüksek yüzdelerin etliekmek ve bamya çorbasında olduğu tespit edilmiştir.

\footnotetext{
* Bu çalışma, Burcu Ayşenur AKBULUT'un 2019 yılında Prof. Dr. İrfan YAZICIOĞLU'nun danışmanlığında gerçekleştirdiği “Destinasyon Markası Oluşumunda Gastronomik Kimlik ve İmaj: Konya Örneği” başlıklı doktora tezinden türetilmiştir.
}

Anahtar Kelimeler: Gastronomi, Gastronomik Kimlik, Gastronomik İmaj, Konya Mutfağı.

Makale Gönderme Tarihi: 29.10.2019

Makale Kabul Tarihi: 08.01.2020

\section{Önerilen Atıf:}

Akbulut, B. A. ve Yazıcıŏlu, İ. (2020). Destinasyon Markası Oluşumunda Gastronomik Kimlik ve İmaj: Konya Örneği, Türk Turizm Araştırmaları Dergisi, 4(1): 100-120.

(c) 2020 Türk Turizm Araştırmaları Dergisi. 


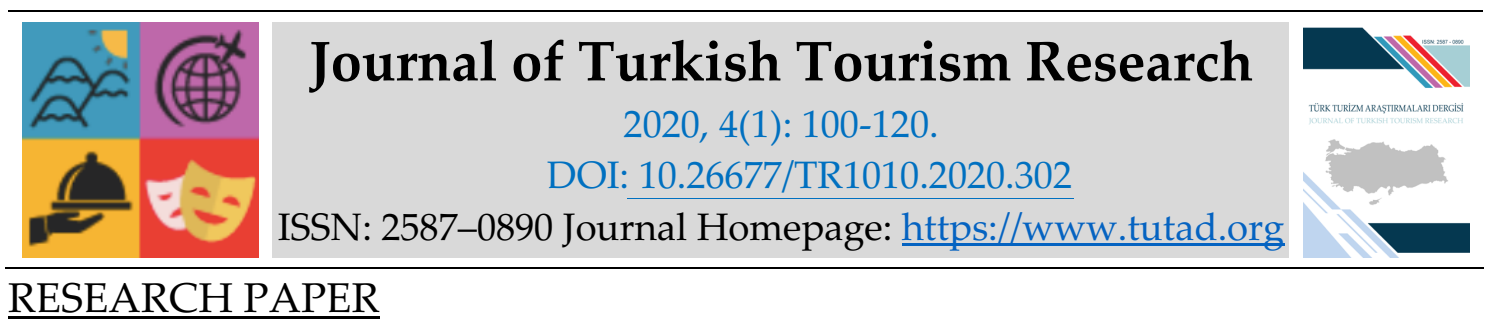

\title{
Gastronomical Identity and Image in Destination Brand Formation: The Case of Konya Cuisine
}

Assistant Prof. Dr. Burcu Ayşenur AKBULUT, Recep Tayyip Erdogan University, Ardesen Faculty of Tourism, Rize, e-mail: burcuaysenur.akbulut@erdogan.edu.tr ORCID: https://orcid.org/0000-0002-0679-3692

Prof. Dr. İrfan YAZICIOĞLU, Ankara Hacı Bayram Veli University, Faculty of Tourism, Ankara, e-mail: irfanyaz@gazi.edu.tr ORCID: https://orcid.org/0000-0002-8575-0817

\begin{abstract}
Determining inimitable branding elements for destinations has become a necessity owing to a host of reasons including the dynamics of the tourism market, changing demands and expectations of tourists, and the need to sustain competitive edge of tourist destinations. The gastronomical identity and image of a region develops as people associate specific food and beverages with that specific region. Gastronomical identity and image differ from destination to destination, and such differences contributes to the hard to copy, genuine, and symbolic features of destinations. The purpose of this study was to determine the identity and image elements influencing destination brand formation. In this study, in accordance with the gastronomic image model, the relationship between affective gastronomic image, cognitive/perceptual gastronomic image, overall gastronomic image and the effect of overall gastronomic image on the overall destination image were determined. Quantitative means of data collection were utilized in the study. The data collection instrument consisted a gastronomical image perceptions scale and a structured open-ended question form. The target population of the study was tourist who visited Konya Province between on 3th December 2017- 15th August 2018. The participants were gathered through convenience sampling and 404 tourists participated in the study. The data were analyzed employing structural model tests, $t$-Test and ANOVA. The results indicated that (a) overall gastronomical image had a subsantial effect on destination image, (b) affective image had a subsantial effect on cognitive/perceptual image and overall gastronomical image, and (c) cognitive/perceptual image had a moderate effect on overall gastronomical image. Moreover, the most frequent responses associated with Konya's gastronomical brand perception were etliekmek (meat bread) and okra soup.
\end{abstract}

Keywords: Gastronomy, Gastronomical Identity, Gastronomical Image, Konya Cuisine.

Received: 29.10.2019

Accepted: 08.01.2020

\section{Suggested Citation:}

Akbulut, B. A. and Yazıcıoğlu, İ. (2020). Gastronomical Identity and Image in Destination Brand Formation: The Case of Konya Cuisine, Journal of Turkish Tourism Research, 4(1): 100-120.

(C) 2020 Türk Turizm Araştırmaları Dergisi. 


\section{GİRIŞ}

Destinasyonların markalaşmasında gastronominin etkisi her geçen gün artmaktadır. Dünya Turizm Örgütü'nün sunduğu Gastronomi Turizmi Raporu'na göre, yeme-içme harcamalarının dünya turizm gelirleri içerisindeki payı $\% 30$ seviyesindedir. Ayrıca destinasyon seçme kararında yemeğin önemli olduğunu ifade eden turistler \%88,2 oranındadır (TÜRSAB, 2014). Birleşmiş Milletler Dünya Turizm Örgütü'nün düzenlediği, 2017 yılında üçüncüsü İspanya'da gerçekleştirilen Gastronomi Turizmi Forumu yapılmış ve gastronominin, destinasyon farklılaşması ve değerinin sunulmasında bir anahtar kaynak olmasının yanı sıra tek başına bir pazar bölümü haline geldiği vurgulanmıştır (Dünya Turizm Örgütü, 2017). Turistler daha önce görmedikleri otantik ve kültürel değerleri görmek, deneyim kazanmak istemekte ve bir ülkenin yöresel yiyecek ve içeceklerini deneyimleme arzusu içinde olmaktadırlar (Seyitoğlu ve Çalışkan, 2014) Günümüzde turistlerin, özel bir yemek türünü tatmak, ünlü bir şefin yemeğini yemek ve gastronomi festivallerini ziyaret etmek gibi etkenlerle turist hareketliliğini sağladıkları bilinmektedir (Yazıcıoğlu ve Akbulut, 2018). Gastronomik motivasyonlarla destinasyonlar ziyaret edilmese bile, bir destinasyonun gastronomik unsurları o destinasyonun kimliğini oluşturmakta ve olumlu ya da olumsuz imajlar yaratabilmektedir. Mevcut pazarın dinamikleri, turistlerin istek ve arzularının değişimi, destinasyonların doğru marka unsurlarının dolayısıyla doğru ve güçlü kimlik unsurlarının belirlenmesi zorunluluğu gibi nedenler bir destinasyonun gastronomik kimliği ve gastronomik imajının belirlenmesinin önemini ortaya koymaktadır.

Mevcut literatür incelendiğinde; gastronomi ve turizm ilişkili yapılan çalışmalar arasında gastronominin destinasyon tercihi ve tekrar ziyaret etme niyetine etkisi (Kivela ve Crotts, 2009; Nam ve Lee, 2011; Aydoğdu, Özkaya Okay ve Köse, 2016; Şen ve Aktaş, 2017), destinasyonların gastronomik değerlerinin ve potansiyelinin belirlenmesi ( Cömert, 2014; Aksoy ve Sezgi, 2015; Güzel Şahin ve Ünver, 2015; Batu, 2016; Başaran, 2017; Akyol, 2018; Yıldırım Saçılık, Çevik ve Toptaş, 2018), gastronomi ve turizm ilişkisi (Harrington ve Ottenbacher, 2010; Sarışık ve Özbay, 2015; Yılmaz, 2017; Küçükkömürler, Şirvan ve Sezgin, 2018), destinasyon rekabetçiliği açısından gastronominin önemi (Çalışkan, 2013), seyahat motivasyonları açısından gastronomi (LopezGuzman ve Sanchez-Canizares, 2012; Çalışkan, 2013; Lopez-Guzman, Hernandez-Mogollon ve Di Clemente, 2014; Akdağ, Akgündüz, Güler ve Benli, 2015; Toksöz ve Aras, 2016; Serçek, 2018), gastronomi marka imajı ve aşinalığın destinasyon bağlllı̆̆ına etkisi (İlban, Bezirgan ve Çolakoğlu, 2018), gastronomi müzeleri (Mankan, 2017; Sormaz ve Güneş, 2016), destinasyon markalaşmasında ve gastronomik kimliğin oluşumunda coğrafi işaretli ürünler (Orhan, 2010; Durlu Özkaya, Sünnetçioğlu ve Can, 2013; Yenipınar, Köşker ve Karacaoğlu, 2014; Sandıkçı ve Töre Başat, 2017; Acar, 2018; Suna ve Uçuk, 2018), yöresel ürünler ve gastronomi turizmi açısından değerlendirilmesi (Büyükşalvarcı, Şapcılar ve Yılmaz, 2016; Çapar ve Yenipınar, 2016; Telbakan, 2017; Apak ve Gürbüz, 2018; Bayram, 2018), gastronomik marka değeri (Şengül, 2018), gastronomik deneyimler (Yüksel ve Yüksel, 2003; Quan ve Wang, 2004; Correia, Moital, Da Costa ve Peres, 2008; Kivela ve Crotts, 2009; Sims, 2009; Robinson ve Clifford, 2012; Björk ve KauppinenRäisänen, 2014; Sidali, Kastenholz ve Bianchi, 2015; Erkmen, 2018), gastronomideki yeni eğilimler (Ottenbacher ve Harrington, 2007; Martínez-Monzó, García-Segovia ve Albors-Garrigos, 2013; Çavuş ve Cömert, 2016) gastronomi ve sürdürülebilir bölgesel kimlik ilişkisi (Everett ve Aitchison, 2008; Durlu Özkaya vd., 2013; Lee, Wall ve Kovacs, 2015; Sidali vd., 2015; Özkan ve Aydın, 2018), gastronomik miras farkındalığı (Serçeoğlu, 2014; Ramli, Zahari, Halim ve Aris, 2016; Taştan ve İflazoğlu, 2018), gastro-turistlerin memnuniyet belirleyicileri (Yüksel ve Yüksel, 2003; Correia vd., 2008; Bayram, 2017; Artuğer ve Fidan, 2018; Başarangil ve Tokatlı, 2018), şehirlerin restoran konseptleri ve pazarlanması (Gehrels ve Kristanto, 2007; Schulp ve Tirali, 2008; Lu, Gursoy ve Lu, 2015; Teyin, Aslan, Sormaz, Pekerşen ve Nizamlığlu, 2017; Akoğlu ve Öztürk, 2018), geleneksel restoran memnuniyetleri ve kalite algisı (Ha ve Jang, 2010; Nam ve Lee, 2011), 
duyusal özellikli destinasyon marka oluşumu (Diţoiu ve Căruntu, 2014), yemek programları ve gastronomik kimlik ilişkisi (Gunders, 2008), gastronomi turları (Kızılırmak, Ofluoğlu ve Şişik, 2016), destinasyon pazarlamasında mutfakların rolü (Okumus, Okumus ve McKercher, 2007; Horng ve (Simon) Tsai, 2010; Yazıcıoğlu, Yaylı, Şahbaz ve Yüksel, 2017) kültürel miras ve gastronomi arasındaki ilişki (Westering, 1999; Nilsson, Svärd, Widarsson ve Wirell, 2011), turizm imajı açısından tarım ve gıda politikaları (Hjalager ve Corigliano, 2000), destinasyon markalaşmasında gastro-turizm (Williams, Williams Jr ve Omar, 2014), destinasyon markalamasında destinasyon kimliği unsuru olarak gastronomi (Lin, Pearson ve Cai, 2011; Aslan, Güneren ve Çoban, 2014; Kılıçhan ve Köşker, 2015; Tüfekçi, Kalkan ve Tüfekçi, 2016; Altaş, 2017), gastronomik kimlik ve oluşum süreci (Harrington, 2005; Fox, 2007), gida/gastronomi imaj1 (Hjalager ve Corigliano, 2000; Frochot, 2003; Karim, 2006; Lin vd., 2011; Eren, 2016; Chang ve Mak, 2018) şeklindedir. Gastronomi ve turizm ilişkili pek çok çalışmaya rağmen gastronomik imaj çalışmaları oldukça azdır. Destinasyonlarda gastronomik imaj algısının nasıl oluştuğuna yönelik çalışmaların ortaya konması gastronomi turizmi, destinasyon markası, dolayısıyla destinasyonların pazarlanması açısından oldukça önem arz etmektedir.

\section{DESTINASYON MARKALAŞMASINDA GASTRONOMI}

Marka; sembollerle ya da kelimelerle ifade edilen, bir ürün ve hizmeti benzerlerinden ayırmayı ve tercih edilirliğini etkileyen bir unsurdur (Eroğlu, 2018). Uztuğ (1999)'a göre bir marka, imaj ve kimlik olarak iki temel bileşenden oluşmaktadır. Marka kimliği, imaj oluşturmada temel belirleyici iken; marka imajı, marka kimliğine ilişkin bileşenlerin algılanması sonucu zihinde oluşan sentez olarak ifade edilir (Yavuz, 2007). Destinasyonlar, rakipler karşısında farklılaşma yoluyla pek çok fayda sağlarlar. Destinasyon markalaşması, destinasyonların sahip olduğu kaynakların etkin bir şekilde kullanılması yoluyla olmaktadır. Bir destinasyonun gastronomisi, destinasyonun benzersiz, özgün ve taklit edilemeyen nitelikleri arasında yer almaktadır. Destinasyonlarda yer alan özgün yiyecek ve içeceklerin, bölge insanlarına özgü deneyim ve tekniklerle üretilmesi ve sunulması destinasyonları farklılaştıran özellikler arasındadır. Turistik bir destinasyonlarda yöresel ürünler ve yemekler, coğrafi ve menşe işaretli gastronomik ürünler turistlerin seyahatlerinde önemli çekicilik unsurları arasında yer alır. Bir diğer önemli nokta ise marka ile bağlantılı her şeyi ifade eden marka çağrışımlarıdır. Bir destinasyonun marka çağrışımları arasında gastronomik öğelerin bulunması o destinasyonun marka değerinin gastronomik unsurlarla şekillenmesi ve desteklenmesi gerektiğini göstermektedir. Destinasyon markası kapsamında çağrışımlar, tüketicilerin marka unsuru olan nesneyi zihninde canlandırması yoluyla, markayı tanımasına yönelik olumlu duygular uyandırması ve markayı farklılaştırması açısından önem arz eder.

Gastronomi, Yunancada "gastro" (mide) ve "nomos" (kural, yasa) kelimelerinin birleşiminden oluşmaktadır. Gastronomi en genel tanımıyla kültür ile yemek arasındaki ilişkiyi araştıran yeme içme bilim ve sanatıdır. Geniş anlamıyla ise gastronomi; kültür, tarih, yetenek, tecrübe vs. unsurlarla harmanlanmış güzel bir yemek hazırlanması, sunumu ve hazırlanan üründen tüketicinin haz duyması aşamasına kadar geçen süreçte bir gastronomun emeğinin sergilenmesidir (Aksoy ve Sezgi, 2015). Son yıllarda gastronomiyle ilgili araştırmalar artış gösterdiği görülmektedir. Bu araştırmalar gastronomiyi oluşturan unsurlar ya da gastronominin etkilediği unsurlara yönelik olabilmektedir.

Destinasyon markalaması kapsamında gastronomiyi inceleyen çalışmalar; destinasyon markalaşmasında gastronominin önemi (Kılıçhan ve Köşker, 2015) yerel mutfak deneyimleri ve marka denkliği ilişkisi (Erkmen, 2018), destinasyon markalaşması kapsamında gidalar (Lin vd., 2011; Lee vd., 2015) turizm pazarlamasında yerel mutfakların rolü (Aslan vd., 2014) şehir markası 
oluşturma sürecinde aşçlık kültürü (Hoşcan, Genç ve Şengül, 2016) coğrafi işaretli ürünlerin destinasyon markası kapsamında değerlendirilmesi (Yenipınar vd., 2014; Acar, 2018; Suna ve Uçuk, 2018), gastronomik marka (Gordin ve Trabskaya, 2013; Pearson ve Pearson, 2017) şeklindedir. Ayrıca Okumus vd., (2007) turizm destinasyonları pazarlamasında yerel ve uluslararası mutfakların dahil edilmesini konu edindikleri araştırmada, iki farklı ülkenin (Hong Kong ve Türkiye) mutfaklarının pazarlama faaliyetlerinde nasıl kullanıldıklarını belirlemişledir. Araştırma sonuçlarına göre Hong Kong'un temel konumlandırma söyleminin içerisinde yoğun bir şekilde gıdaları kullandığı, Türkiye'nin yerel mutfağının son derece zengin olmasına rağmen pazarlama araçlarında çok az referans verdiği görülmüştür. Yazarlar uzmanlık ve bilginin öneminden bahsetmişler ve destinasyonların kendilerini farklılaştırmak için özgün mutfak kültürlerini kullanmaları üzerine önerilerde bulunmuşlardır. Lu vd., (2015) müşterilerin özgünlük algısı ile marka eşitliği boyutları arasındaki ilişkinin belirlenmesi ve etnik restoranların marka seçim niyeti üzerinde marka eşitliğinin etkisini incelemişlerdir. Özgünlük algısının marka eşitliği ile anlamlı bir ilişkisi ortaya konurken, marka seçim niyeti üzerinde marka eşitliğinin de etkisi olduğu bulunmuştur. Lee vd., (2015) destinasyon markalaması üzerinden gıda kümelenmesinin oluşumu ve kırsal bölgelerin gelişimi üzerinde hazırladıkları çalışmada, kırsal gelişimin yaratılmasında gıda kümelenmelerinin nasıl sağlandığı, paydaşların iş birliği ve bu oluşum önündeki başarı ve engelleri Kanada' da yer alan iki bölgenin karşılaştırmalı analizi ile sunmuşlardır. Şengül (2018) ise gastronomi marka değeri bileşenlerinin seyahat niyeti üzerindeki etkisini araştırmış ve araştırma kapsamında Bolu'ya gelen turistlerin marka değeri algısının olumlu olduğunu, gastronomi marka değeri bileşenlerinin ise seyahat niyetini pozitif yönde etkilediğini ortaya koymuştur. En güçlü etkinin marka sadakati bileşeni olduğu belirtilmiştir.

\section{Gastronomik Kimlik ve Konya Gastronomik Kimliğini Etkileyen Unsurlar}

Kimlik, herhangi bir nesneyi belirlemeye yarayan nitelik ve özelliklerin bütünü olarak tanımlanmaktadır (Türk Dil Kurumu, 2018). Destinasyon kimliği, bir yerin nitelik ve özelliklerinin bütünü ve diğer yerlerden farklılaştıran tüm özellikleri şeklinde tanımlanabilir. Gastronomik kimlik ise, bir destinasyonun sahip olduğu gastronomik niteliği ve özelliklerinin bütünü olarak tanımlanabilir. Harrington (2005) gastronomik kimliği, çevresel ve kültürel bileşenlerin bütünü olarak tanımlamıştır. Harrington (2005) bir destinasyonun gastronomik kimlik oluşumunu incelemiş ve pek çok durumun gastronomik kimliğe etki ettiğini ifade etmiştir. Fox (2007) gastronomik kimlik oluşumu ve bu kimliğin sunulmasına yönelik hazırladığ çalışmada, turistik destinasyonlarda gastronomik kimliğin yeniden keşfini incelemiş ve gastronomik kimliğin oluşum sürecini farklılaştırma, estetikleştirme, özgünleştirme, sembolleştirme ve eskinin canlandırılması şekline yorumlamıştır. Danhi (2003) de gastronomik kimlikle ilgili çalışmalar yapmış ve gastronomik kimliği coğrafya, tarih, etnik çeşitlilik, mutfak görgü kuralları, yaygın lezzetler ve yemek reçetelerinden oluşan altı faktör üzerinden tanımlamıştır. Gastronomik kimlikle ilgili çalışamalar ortaya koyan Fox (2007), Hırvatistan destinasyonlarında bölge mutfağı farklılaştıran unsurların ortaya konması, geleneksel yiyecek ve tatlara kendine özgü estetik değer katılması, taklit edilemez ve özgün gastronomik kimlik unsurlarının belirlenmesi ve simgesel olarak ifade edilmesi, gastronomide eski geleneğin yeniden canlandırılması gerekliliğine vurgu yapmıştır. Yazar çalışmasında, iletişimsel gastronomiden bahsetmiş ve gastronomik kimliğin gastronomiye özgü bir iletişimle duyurulması gerekliliğini savunmuştur. Çalışkan (2013) ise gastronomik kimlik ile ilgili yapılan çalışmalarını incelemiştir. Gastronomi turizmi ile gastronomik kimlik ilişkisinin yansıra gastronomik kimliğin destinasyon rekabetçiliğini arttırmaya ve turistlerin seyahat motivasyonuna etkisine yönelik bir bakış açısı sunmuştur. 
Konya mutfağı, sahip olduğu kültürel ve tarihi özelliklerden, coğrafya ve iklim özelliklerden, inanç iklimi ve sosyal yapılardan fazlasıyla etkilenmiştir. Konya mutfağ kültürel ve tarihsel açıdan değerlendirildiğinde; dünya gıda tarihi açısından büyük bir öneme sahip olan ve Neolitik kentlerden belki de en önemlisi Çatalhöyük, Konya'yı dünya gıda antropolojisi açısından öne çıarmaktadır (Baysal ve Wright, 2005). Konya gastronomisini etkileyen ve şekillendiren bir diğer unsur Selçuklu mutfağı özellikleridir (Akkor, 2014; Halıcı, 2015). Anadolu Selçukluları döneminde Konya'nın başkent olması, Türk mutfağını en iyi yansıtan yerlerden biri olmasını sağlamış ve bugünkü Konya mutfağını şekillendirmiştir. Konya mutfağı, gıda sosyolojisi açısından değerlendirildiğinde ise Konya gastronomik kimliği içerisinde öne çıan en önemli unsur özel gün yemekleri ve gelenekleridir. Konya' da şekillenen sofra kültürü şüphesiz bölgenin tarihi zenginliğinden etkilenmiş olup, düğün yemeklerinde ise Konya'ya özgü bir sunumun ortaya çıtığ görülmektedir. Gastronomik unsur üzerine kurulu bir diğer gelenek ise "şivlilik" olarak ortaya çıkmaktadır. 2014 yılında Kültür ve Turizm Bakanlığı'nın somut olmayan miras olarak kayıt altına aldığı şivlilik geleneği, üç ayların gelişiyle gece fenerlerle kapıları çalan çocuklara yemiş, çerez gibi kolay yenilebilir yiyeceklerin yanı sıra "bişi" (hamur kızartması) gibi yiyeceklerin verilmesiyle gerçekleşir. Konya gastronomisini özgün kılan unsurlardan belki de en önemlisi Mevlevi mutfağıdır (Aksoy, Akbulut ve İflazoğlu, 2016). Hem yeme-içmenin sosyolojik boyutu hem inançlar açısından kendine has gastronomik özelliklere sahip olan Mevlevi mutfağı, Konya gastronomisi için oldukça önem arz etmektedir. Konya gastronomisi sahip olduğu doğal özellikler açısından değerlendirildiğinde, sahip olduğu gastronomik özelliklerin coğrafi ve iklimsel dolayısıyla tarımsal özelliklerinden etkilenmektedir. Konya'da tahıl ürünleri ve şeker pancarı üretiminin öne çıktığı görülmektedir. Bu durumun Konya gastronomisine, un ve unlu mamullerinin oldukça önemli olması, pide çeşitleri ve pek çok çeşidi bulunan şekerleri ile yansıdığı söylenebilir. Ayrıca Konya, üç tane tescillemiş olan menşe adı ve üç tane tescillenmiş mahreç işareti alan gastronomik unsurları ile coğrafi işaretler açısından da öne çıkmaktadır. Tüm bu özelliklerle gerek özgün gastronomik kimlik sağlamada gerekse olumlu gastronomik imaj ve hatırlanabilir deneyimler yaratmada Konya'nın zengin bir gastronomik kimliğe sahip olduğu görülmektedir

\section{Gastronomik İmaj}

İmaj kelimesi, Fransızca kökenli olup genel görünüş, izlenim anlamına gelen "imge" sözcügü ile ifade edilmektedir (Türk Dil Kurumu, 2018) İmge kelimesinin, özellikle pazarlama çalışmalarında imaj kavramını açıklama güçlüğü nedeniyle bu çalışmada imaj ifadesi kullanılmıştır. İmaj, algılama sonucu edinilen tüm bilgilerin zihinsel bir tasarımıdır. İmaj, turizm hareketliliklerini biçimlendiren önemli bir etken olarak şekillenmektedir (Şahbaz ve Kılıçlar, 2009: 34). Gastronomik imaj, bir destinasyonun gastronomik ürünler ve yemek kültürü hakkında oluşan tüm izlenimleri olarak tanımlanmaktadır. Chang ve Mak (2018) destinasyonlarda gastronomik imaj oluşumunda sofra adabı, görgü kuralları, yeme alışkanlıkları, ünlü gıdaların ve yemeklerin gastronomik imajda bilişsel ifadeleri temsil ederken, gıdaların sembolik anlamlarının ise gastronomik imajın duygusal yönleriyle ilişkisi olabileceğini ifade etmişlerdir. Gastronomik imaj ile ilgili çalışmalar gastronomik kimlikte olduğu gibi oldukça azdır. Gastronomik imaj ile ilgili çalışmalar daha çok turizm imajı açısından tarım ve gıda politikaları (Hjalager ve Corigliano, 2000), gida ya da gastronomi imajı (Hjalager ve Corigliano, 2000; Frochot, 2003; Karim, 2006; Lin vd., 2011 Eren, 2016; Chang ve Mak, 2018) çalışmaları üzerinden şekillenmektedir. Karim (2006) benzersiz sokak yemeği satıcıları, sokak pazarı ziyaret olanakları, egzotik pişirme teknikleri, benzersiz kültürel deneyim, restoranlara kolay erişim, özellikli restoranlar, uluslararası restoran menülerinin, gıda ve şarap ilişkili turlar, yiyecek ve şarap bölgeleri, gidalara ilişkin çeşitlilik, çeşitli yemek aktiviteleri, yemek pişirme dersleri ve çiftlik 
ziyaretleri ifadelerinden oluşan gıda imajı ölçeği oluşturmuştur. Karim (2006) Fransa, İtalya ve Tayland ülkelerinin gastronomik imajını karşılaştırmalı olarak ortaya koyduğu çalışmada, oluşturduğu ölçekte gıda imajı, benzersiz imaj, restoran imajı şeklinde üç boyut belirlemiştir. Frochot (2003) ise Fransız bölgesel turizm broşürlerinde kullanılan veriler ışığında gıda imajını ortaya koymayı amaçlamıştır. Araştırmacı, ülkenin gıda imajında kullanılan görüntülerde, ürün/yemek, ham/doğal ürünlerin baskın olduğunu bunu ise şarap ve üzüm bağları görüntülerinin takip ettiğini gözlemlemiştir. Chang ve Mak (2018) turistlerin mutfakla ilgili bakış açılarını belirlemek üzere görüşme yöntemi kullandıkları çalışma sonucunda, gıdalara yönelik algılamalar için çekicilikler, lezzet profili, aşinalık, pişirme yöntemi/içerikleri, ayırt edilebilirlik, uygunluk /fiyat ve sağlık/güvenlik gibi yedi kategori şeklinde sınıflandırma yapmışlardır. Eren (2016) ise Türkiye'nin gastronomi imajı üzerine hazırladığı çalışmada gastronomi imajı ve bilgi kaynağının, tekrar ziyaret etme niyeti üzerindeki etkisini incelemiş ve söz konusu iki unsurun tekrar ziyaret etme niyeti üzerinde etkisi tespit edilmiştir. Gastronomik imaj algısının nasıl oluştuğuna yönelik çalışmaların ortaya konması gastronomi turizmi, destinasyon markası, dolayısıyla destinasyonların pazarlanması açısından önemlidir. İlban vd. (2018) destinasyon bağlılığı yaratmada gastronomi marka imajı ve gastronomi aşinalığının rolü üzerine yaptıkları çalışmalarında gastronomi aşinalığı ve gastronomi marka imajının destinasyon bağ llılığı üzerinde anlamlı ve pozitif etkisi olduğu tespit edilmiştir.

Gastronomik imaj çalışmalarına bakıldığında, gastronomik imaj boyutlarının belirlenmesine yönelik oldukça az çalışma olduğu görülmektedir. Bu araştırma destinasyon imajı modelini temel alarak gastronomik imaj oluşumunu anlamaya çalışmakta ve bu yönüyle alanyazına katkı sağlamayı hedeflemektedir. Araştıma kapsamında oluşturulmuş gastronomik imaj modeli doğrultusunda, duygusal gastronomik imaj, bilişsel/algısal gastronomik imaj, genel gastronomik imaj arasındaki ilişkinin ve genel gastronomik imajın genel destinasyon imajını etkileme düzeyi belirlenmiş̧ir.

\section{Araştırma Hipotezleri}

$\mathbf{H}_{\mathbf{1}}$ : Konya'yı ziyaret eden turistlerin duygusal gastronomik imaj algılarının bilişsel/algısal gastronomi imaj algıları üzerinde olumlu etkisi vardır.

$\mathbf{H}_{2}$ : Konya'yı ziyaret eden turistlerin duygusal gastronomik imaj algılarının genel gastronomi imaj algıları üzerinde olumlu etkisi vardır.

$\mathbf{H}_{3}$ : Konya'yı ziyaret eden turistlerin bilişsel/algısal gastronomik imaj algılarının genel gastronomi imaj algiları üzerinde olumlu etkisi vardır.

$\mathbf{H}_{4}$ : Konya'yı ziyaret eden turistlerin genel gastronomik imaj algılarının genel destinasyon imaj algıları üzerinde olumlu etkisi vardır.

\section{YÖNTEM}

Çalışmada, nicel araştırma yöntemi benimsenmiştir. Araştırmada bilgiler anket formu yoluyla toplanmıştır. Araştırmada, örneklem seçimi için tesadüfi olmayan örnekleme yöntemlerinden biri olan kolayda örneklem yöntemi tercih edilmiştir. Buna göre araştırmacı şehirde yaşamayan, sadece Konya şehrini ziyaret eden kişilerden bilgi toplamıştır. Şehrin gastronomik imaj algılarını ölçmede asgari örneklem sayısı belirlenmesinde Yamane (2001: 116)'nın örneklem seçim formülünden yararlanılmıştır. Buna göre; Kültür ve Turizm Bakanlığı verilerine göre 2018 yılı içerisinde Konya'yı ziyaret eden yabancı ziyaretçi sayısı 63.598' dir. Yerli ziyaretçilerin sayısını belirlenmemiş olsa da Türkiye genelinde en çok ziyaret edilen müzeler arasında yer alan Konya Mevlâna Müzesi ziyaretçi sayısı 2018 yılı içerisinde 2.961.078 olarak belirlenmiştir. Araştırmada ise yerli ve yabancı turist sayısı toplamı 3.024.676 kişi olarak değerlendirilmiştir. Kullanılan örneklem tahmini formülü sonucunda 0,05 anlamlllık düzeyi ile örneklem sayısı 384 
bulunmuştur. Araştırmada verilerin toplanmasında, yüz yüze görüşme yolu tercih edilmiştir. Aralık ayında gerçekleşen Şeb-i Arus törenlerine gelen ziyaretçileri kapsaması ve yazın seyahat eden turistleri kapsaması için 3 Aralık 2017- 15 Ağustos 2018 tarihleri arasında Konya'yı ziyaret eden turistlere uygulanmış ve 424 anket formu elde edilmiştir. Anket formlarının eksik veri nedeniyle 20'si elenmiş ve 404'ü kullanılmıştır. Alanyazın incelenerek ve Konya mutfağ 1 özellikleri göz önüne alınarak hazırlanan anket formu ile 50 katılımcı üzerinde pilot uygulama yapılmıştır. Yapılan pilot uygulama sonucuda güvenirlik analizi yapılmış ve Cronbach's Alpha değeri 0.85 bulunmuştur. Anketin güvenirliği yeterli görülse de bir ifadenin normal dağılım sergilemediği tespit edilmiştir. Ayrıca beş anket formunda aynı ifadenin boş bırakılması nedeniyle, katılımcılar tarafından tam anlaşılamadığı sonucuna varılmış ve ifade anket formundan çıkarılmıştır. Diğer ifadelerde sorun görülmemiş ve verilerin toplanılmasına devam edilmiştir. Veri toplama araçlarından anket kullanılan araştırmada, gastronomik imaj ölçeği mevcut çalışmalar (Baloğlu ve McCleary, 1997; Beerli ve Martin, 2004; Karim, 2006; Lin vd., 2011; Eren, 2016; Chang ve Mak, 2018) ve Konya'nın sahip olduğu gastronomik kimlik özellikleri dikkate alınarak oluşturulmuştur. İngilizce ve Türkçe olarak hazırlanan ankette, ziyaretçilerin kişisel özelliklerini belirlemeye yönelik sorular, Konya gastronomik unsurlarının belirlenmesine yönelik olarak açık uçlu sorular, genel Konya mutfağı imajını belirlemeye yönelik tek ifadede sorulmuş soru ve 17 ifadeden oluşan 5'li Likert tipte oluşturulmuş gastronomik imaj ölçeği soruları yer almaktadır.

Araştırmada, nedensel ilişkileri test edilmesini sağlayan, tahmin eden ve yapısal teorilerin doğrulanmasında kullanılan istatiksel bir yaklaşım olarak tanımlanan yapısal eşitlik modellemesi (YEM) kullanılmıştır. Kısmi en küçük kareler yapısal eşitlik modellemesi, örneklemi test edip doğrulayarak açımlayıcı araştırma modellerinde uygulanabilmesi, tahmin odaklı araştırmalarda ve nedensel öngörü analizinde güçlü bir araç olmasının yanı sıra kayıp veri olduğunda çalışabilmesi ve normalite gibi koşulları istememesi gibi nedenlerle tercih edilen bir analiz yöntemidir (Alkış, 2016; Hair, Hult, Ringle ve Sarstedt, 2017; Uşaklı ve Küçükergin, 2018). Ayrıca araştırmada seçilmesinin bir diğer nedeni ise bir veya iki ifadeli değişkenlerle de analize imkân vermesidir. Araştırmada yapısal eşitlik modellemesi için, ulaşım kolaylığı nedeniyle SmartPLS istatistik paket programı kullanılmıştır.

\section{BULGULAR}

Bu bölümde araştırmaya katılan ziyaretçilerin sosyodemografik özellikleri ve yapısal eşitlik modeli sonuçlarına yönelik raporlar yer almaktadır.

\section{Katılımcıların Sosyodemografik Özelliklerine İlişkin Bulgular}

Katılımcıların sosyodemografik özellikleri Tablo 1'de yer almaktadır. Cinsiyet açısından bakıldığında, katılımcıların \%44,8'i erkek, \%55,2'si kadındır. Katılımcıların yaş durumlarına bakıldığında orta yaşın çoğunlukta olduğu söylenebilir. Medeni durumları değerlendirildiğinde $\% 43,3$ 'ü bekar, $\% 52,7^{\prime}$ 'si ise evlidir.

Eğitim durumları açısından bakıldığında \%50,5 oranıyla çoğunun üniversite eğitimi aldıkları görülmektedir. Katılımcıların meslek durumlarına göre İşçi/Şirket Çalışanı $(\% 22,3)$ grubunda olanların en fazla, Sanatçı $(\% 2,2)$ grubunda olanların ise en az olduğu görülmektedir. Katılımcıların gelir durumlarına bakıldığında \%49 "1001-3000 TL" arasında olduğu, "7001 TL ve üstü" geliri olan turistin az olduğu görülmektedir. 
Tablo 1. Katılımcların sosyodemografik bilgileri

\begin{tabular}{|c|c|c|c|c|c|}
\hline Cinsiyet & $\mathrm{n}$ & $\%$ & Medeni Durum & $\mathbf{n}$ & $\%$ \\
\hline Erkek & 181 & 44,8 & Bekar & 175 & 43,3 \\
\hline Kadin & 223 & 55,2 & Evli & 229 & 56,7 \\
\hline Toplam & 404 & 100 & Toplam & 404 & 100 \\
\hline Yaş Durumu & $\mathbf{n}$ & $\%$ & Gelir durumu & $\mathbf{n}$ & $\%$ \\
\hline $18-24$ & 85 & 21 & 1000 TL ve alt1 & 73 & 18,1 \\
\hline $25-34$ & 129 & 31,9 & $1001-3000 \mathrm{TL}$ & 198 & 49 \\
\hline $35-50$ & 113 & 28 & $3001-5000 \mathrm{TL}$ & 97 & 24 \\
\hline $51-64$ & 53 & 13,1 & $5001-7000 \mathrm{TL}$ & 21 & 5,2 \\
\hline 65 ve üstü & 24 & 5,9 & $7001 \mathrm{TL}$ & 15 & 3,7 \\
\hline Toplam & 404 & 100 & Toplam & 404 & 100 \\
\hline Eğitim Durumu & $\mathbf{n}$ & $\%$ & İkametgâh & $\mathbf{n}$ & $\%$ \\
\hline Lise ve altı & 163 & 40,3 & İstanbul & 77 & 19,1 \\
\hline Üniversite & 204 & 50,5 & Ankara & 55 & 13,6 \\
\hline Lisansüstü & 37 & 9,2 & İzmir & 27 & 6,7 \\
\hline Toplam & 404 & 100 & Antalya & 23 & 5,7 \\
\hline Mesleki Durum & $\mathbf{n}$ & $\%$ & Yurtdışı & 20 & 5,0 \\
\hline Öğretmen/Akademisyen & 42 & 10,4 & Diğer & 202 & 50,0 \\
\hline Ev Hanımı & 61 & 15,1 & Toplam & 404 & 100 \\
\hline Sanatçı (Ressam, Müzisyen v.b.) & 9 & 2,2 & Memleket (Bölgelere göre) & $\mathbf{n}$ & $\%$ \\
\hline Yönetici/Kamu İdarecisi & 39 & 9,7 & \multirow{2}{*}{$\begin{array}{l}\text { Ege, Marmara ve Akdeniz } \\
\text { Bölgeleri }\end{array}$} & \multirow{2}{*}{140} & \multirow{2}{*}{41,1} \\
\hline Öğrenci & 49 & 12,1 & & & \\
\hline Avukat, Mühendis, Doktor & 18 & 4,5 & İç Anadolu Bölgesi & 132 & 38,7 \\
\hline İşçi/Şirket Çalışanı & 90 & 22,3 & Karadeniz Bölgesi & 42 & 12,3 \\
\hline Emekli & 49 & 12,1 & \multirow{2}{*}{$\begin{array}{l}\text { Doğu Anadolu-Güneydoğu } \\
\text { Anadolu Bölgeleri }\end{array}$} & \multirow{2}{*}{27} & \multirow{2}{*}{7,9} \\
\hline Diğer & 47 & 11,6 & & & \\
\hline Toplam & 404 & 100 & Toplam & 341 & 100,0 \\
\hline
\end{tabular}

Katılımcılara yaşadığı şehirler açık uçlu soru şeklinde sorulmuş ve en fazla yazılan iller Tablo 1'de sıralanmıştır. İstanbul, Ankara, İzmir ve Antalya ilinden Konya'yı ziyaret eden turistlerin çoğunluğu oluşturduğu görülmektedir. Yine katılımcıların memleket durumları açık uçlu soru şeklinde sorulmuş ve cevaplar bölgeler açısından kategorik hale getirilmiş ve Tablo 1'de sunulmuştur. Konya'ya gelen ziyaretçiler memleket açısından değerlendirildiğinde Ege, Marmara ve Akdeniz Bölgeleri ve İç Anadolu Bölgelerinden daha fazla geldikleri görülmektedir. Bu durum, bu bölgelerde yaşayan ziyaretçilerin Konya'ya ulaşmalarının daha kolay olması, nüfusun bu bölgelerde daha fazla toplanması gibi nedenlerle açıklanabilir. Ayrıca Konya'yı ziyaret etme motivasyonları açısından Mevlana Celalettin Rumi önemli bir faktördür ve bu bölgelerde yaşayanların Mevlana'ya olan ilgisinin daha fazla olduğu öne sürülebilir.

\section{Katılımcıların Genel Destinasyon İmaj Algılarına ve Gastronomik Marka Algılarına İlişkin Bulgular}

Araştırmaya katılan turistlerin Konya ile ilgili genel destinasyon imaj algılamaları, tek ifadeli şekilde olumsuzdan (1) olumluya (5) Likert tipte sorulmuştur. Tablo 2'de araştırmaya katılan ziyaretçilerin Konya şehri ile ilgili genel imaj değerlendirmeleri verilmiştir. Konya'nın destinasyon genel imajının olumlu olduğu söylenebilir $(\bar{x}=3,92)$

Katılımcılara Konya'nın gastronomik marka algılarını belirlemek amacıyla Konya Gastronomisi (yeme-içme unsurları) denildiğinde aklan gelen üç unsuru yazmaları istenmiştir. Verilen cevaplar kategorik hale getirilmiştir. Katılımcılardan sıralı olarak 1, 2 ve 3 numaralandırılması yapılarak verilen boşlukları doldurmaları istenmiştir. Toplamda 1011 cevaptan oluşan verilerde, 
Çağrışım 1'de 1, Çağrışım 2'de 53, Çağrışım 3'de 147 boş bırakıldığı tespit edilmiştir. Cevaplar değerlendirildiğinde, pide/etliekmek, çorbalar, et yemekleri/pilav, sebze yemekleri/balık, hamur işleri, tatlılar, içecekler ve şekerleme/lokum/hurma olmak üzere sekiz kategori oluşturulmuştur

Tablo 2. Araştırmaya katılan turistlerin Konya ile ilgili genel imaj algılarının betimsel analizi

\begin{tabular}{|c|c|c|c|c|c|c|c|c|c|}
\hline Genel Destinasyon İmajı & 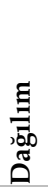 & 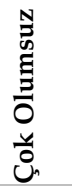 & ڤ્ & $\stackrel{\pi}{0}$ & 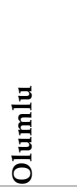 & 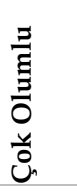 & $\frac{\Xi}{0}$ & 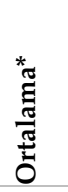 & 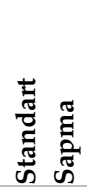 \\
\hline \multirow{2}{*}{ Konya Genel İmaj* } & $\mathbf{f}$ & 5 & 20 & 84 & 189 & 106 & 404 & \multirow{2}{*}{3,92} & \multirow{2}{*}{0,880} \\
\hline & $\%$ & 1,2 & 5,0 & 20,8 & 46,8 & 26,2 & 100 & & \\
\hline
\end{tabular}

Katılımcıların Konya gastronomik marka algıları kategorik açıdan değerlendirildiğinde Pide/Etliekmek $(\% 36,6)$ oranıla en fazla olup, sırasıyla en fazla yüzdeye sahip gastronomik çağrışımlar et yemekleri/pilav (\%22,8) ve çorbalar (\%18,5)'dır. Kelime bazında incelendiğinde, en fazla yazılan çağrışım olarak \%34 ile Etliekmek, ondan sonra en fazla yazılan çağrışım \%14,2 ile bamya çorbasıdır. Çağrışımlar sıralı şekilde değerlendirildiğinde ise, ilk akla gelenlerde (Çağrışım 1), \%74,4 oranıyla Pide/Etliekmek; ikinci akla gelenlerde (Çağrışım 2), \%33 ile et yemekleri/pilav; üçüncü akla gelenlerde ise boş bırakılma durumu artmış olup, \%26,8 oranıyla en fazla yazılan unsur et yemekleri/pilavdır.

\section{Katılımcıların Gastronomik İmaj Algılarına İlişkin Bulgular}

Araştırma katılımcılarına gastronomik imaj ifadelerini Konya Mutfağı üzerinden cevaplandırmaları istenmiş ve ortalama ve standart sapmaları Tablo 3'te verilmiştir. Tabloya göre en fazla ortalamaların "ulaşılabilirdir" ( $\bar{x}=3,88)$, "yiyecek ve içeceklerde kalite açısından tamdır" $(\bar{x}=3,85)$ ve "lezzetlidir" $(\bar{x}=3,84)$ ifadelerinde olduğu görülmektedir. En düşük ortalama ise "yenilikçidir" $(\bar{x}=3,05)$ ifadesinde bulunmaktadır. Diğer yandan 2,73 ortalama ile Konya yemeklerinin rahatsızlık vermediği sonucuna varılabilmektedir.

Tablo 3. Konya'nın gastronomik imaj algısı

\begin{tabular}{|c|c|c|c|}
\hline & IFADELER & $\bar{x}^{*}$ & s.s \\
\hline \multirow{13}{*}{ 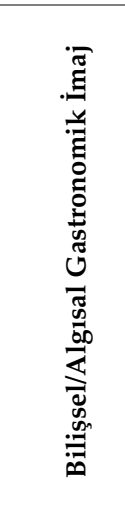 } & Sağllk ve besin değeri açısından uygundur & 3,70 & 1,039 \\
\hline & Yiyecek ve içeceklerde kalite açısından tamdır. & 3,85 & 0,892 \\
\hline & Farklı sunum ya da yeme şekli sunar. & 3,60 & 1,022 \\
\hline & İlgi çekici yiyecek ve içecekler vardır. & 3,61 & 1,031 \\
\hline & Restoranların ilgi çekici atmosferi vardır. & 3,46 & 0,969 \\
\hline & Restoran ya da mutfak çalışanları misafirperverdir. & 3,53 & 1,043 \\
\hline & Özgündür. & 3,65 & 1,038 \\
\hline & Ödenen ücrete değer & 3,59 & 1,033 \\
\hline & Yenilikçidir & 3,05 & 1,231 \\
\hline & Yiyecek ve içecekler estetik görünüm sağlar. & 3,51 & 1,074 \\
\hline & Lezzetlidir & 3,84 & 1,008 \\
\hline & Ulaşılabilirdir. & 3,88 & 0,991 \\
\hline & Yemek çeşitliliği oldukça fazladır. & 3,50 & 1,015 \\
\hline \multirow{3}{*}{ 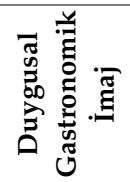 } & Konya yemekleri rahatsızlık verir. & 2,73 & 1,251 \\
\hline & Konya yemeklerini yemek bana keyif verir. & 3,70 & 0,969 \\
\hline & Konya'daki yemeklerin manevi değeri olduğunu düşünürüm. & 3,55 & 1,143 \\
\hline
\end{tabular}


Araştırmaya katılan turistlerin Konya'nın genel gastronomik imajlarına ilişkin tek ifadeli şekilde olumsuzdan (1) olumluya (5) Likert tipte soru sorulmuştur.

Tablo 4. Katılımcların genel gastronomik imaj algılamaları

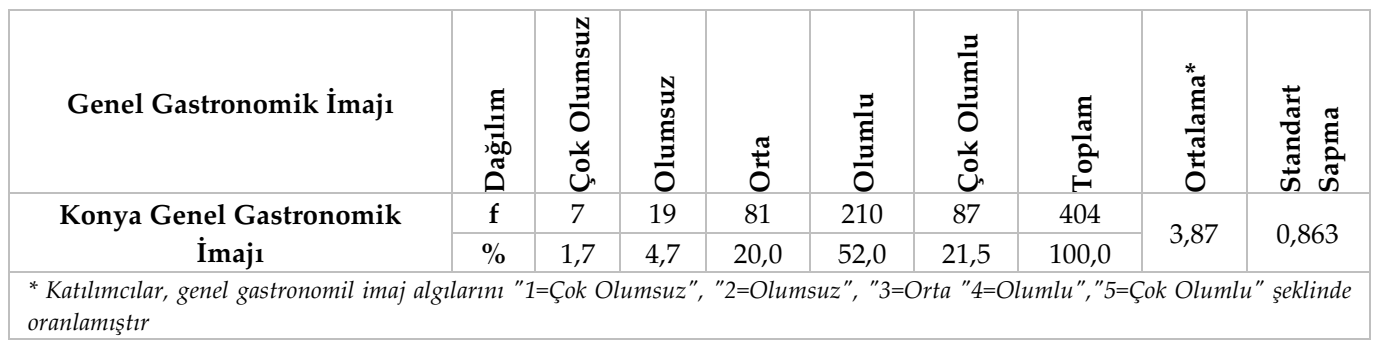

Tablo 4'te araştırmaya katılan ziyaretçilerin Konya genel gastronomik imaj algılarına yönelik değerlendirmeleri verilmiştir. Konya'yı ziyaret eden turistlerin gastronomik imaj algısının imajının olumlu olduğu söylenebilir ( $\bar{x}=3,87)$.

\section{Kısmi En Küçük Kareler Yapısal Eşitlik Modeli (Dışsal ve İçsel Model)}

Araştırma ölçüm modeli, yansıtıcı ölçüm açısından değerlendirilmiş ve öncelikle dışsal model verileri belirlenmiştir. Kısmi en küçük kareler yapısal eşitlik modellemesi yapılırken Hair vd., (2017) ve Uşaklı ve Küçükergin (2018) yönlendirmeleri dikkate alınmıştır. Yazarlar, dışsal model ve içsel model şeklinde değerlendirme yapılmasını ve dışsal modelde çalışmada kullanılan her bir göstergenin listesini, içsel modelde ise tüm yapısal ilişkilerin grafik olarak gösterilmesini önermektedirler.

\section{Dişsal Model}

Uşaklı ve Küçükergin (2018)'nin değerlendirilmeleri dikkate alınarak dışsal model başlığı altında dışsal yükler, yapı güvenirliği, ortalama açıklanan varyans ve ayırt edici geçerlilik verileri belirtilmiştir. Araştırmanın dışsal model sonuçlarından dışsal yükler, yapı güvenirliği, ortalama açıklanan varyans Tablo 5'te yer almaktadır.

Tablo 5. Dışsal model sonuçları

\begin{tabular}{|c|c|c|c|c|}
\hline & BOYUTLAR/İFADELER & Dışsal Yükler & $\begin{array}{c}\text { Yapı } \\
\text { Güvenirliği }\end{array}$ & $\begin{array}{c}\text { Ortalama } \\
\text { Açıklanan } \\
\text { Varyans }\end{array}$ \\
\hline \multirow{9}{*}{ 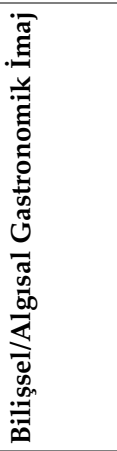 } & Sağlık ve besin değeri & 0,763 & \multirow{9}{*}{0,923} & \multirow{9}{*}{0,570} \\
\hline & Estetik görünüm & 0,729 & & \\
\hline & Lezzetli olması & 0,733 & & \\
\hline & Yiyecek içecek kalitesi & 0,773 & & \\
\hline & Farklı sunum ve yeme şekli & 0,777 & & \\
\hline & İlgi çekici yiyecek ve içecekler & 0,774 & & \\
\hline & İlgi çekici atmosfer & 0,716 & & \\
\hline & Özgünlüğü & 0,783 & & \\
\hline & Ödenen ücrete değerliği & 0,744 & & \\
\hline \multirow{2}{*}{ 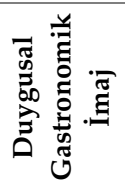 } & Keyif vermesi & 0,888 & \multirow[b]{2}{*}{0,878} & \multirow[b]{2}{*}{0,783} \\
\hline & Manevi değeri & 0,882 & & \\
\hline
\end{tabular}


Uşaklı ve Küçükergin (2018)'in tavsiyeleri doğrultusunda dışsal yükler değerlendirilirken 0.70 'den büyük yükler dikkate alınmış, 0.70 'den küçük yük alan ifadeler analiz dışı bırakılmıştır. Buna göre "restoran ya da mutfak çalışanları misafirperverdir" $(0,29)$, "yenilikçidir" $(0,56)$, "ulaşılabilirdir" $(0,66)$ ve "yemek çeşitliliği oldukça fazladır" $(0,61)$ ifadeleri değerlendirmeye alınmamıştır. Tablo 5'te görüldügü üzere ölçüm yapılan madde yükleri $0,72-0,78$ arasında değişmektedir. Kısmi en küçük kareler yapısal eşitlik modelinde ölçeğin güvenirliği tespit edilirken Cronbach's Alpha değeri yerine yapı güvenirliğinin dikkate alınması önerilir. Yine Tablo 5 'te görüldüğü üzere ölçümün yapı güvenirliği, bir boyutta 0,92 bir boyutta 0,88 şeklinde olup, tavsiye edilen 0,70 'den büyük olma koşulunu sağlamaktadır. Ölçüm modeli ortalama açılanan varyans değerleri açısından değerlendirildiğinde değerlerin 0.5 'den büyük olması önerilir (Hair vd., 2017). Tablo 5'te görüldüğü üzere araştırma modelinin açıklanan varyans değerleri 0.50 'den büyük değer almaktadır.

Tablo 6. Ayırt edici geçerlik ve faktörler arası korelasyon katsayıları

\begin{tabular}{ccccc}
\hline & $\begin{array}{c}\text { Bilişsel/Algisal } \\
\text { Gastronomik İmaj }\end{array}$ & $\begin{array}{c}\text { Destinasyon } \\
\text { İmaj1 }\end{array}$ & $\begin{array}{c}\text { Duygusal } \\
\text { Gastronomik } \\
\text { İmaj }\end{array}$ & $\begin{array}{c}\text { Genel } \\
\text { Gastronomik } \\
\text { İmaj }\end{array}$ \\
\hline Bilişsel/Algısal Gastronomik İmaj & $\mathbf{0 , 7 5 5 ^ { * }}$ & & & \\
\hline Destinasyon İmajı & $0,407^{* *}$ & $\mathbf{1 , 0 0 0}^{*}$ & & \\
\hline Duygusal Gastronomik İmaj & $0,680^{* *}$ & $0,378^{* *}$ & $\mathbf{0 , 8 8 5}^{*}$ & \\
\hline Genel Gastronomik İmaj & $0,609^{* *}$ & $0,561^{* *}$ & $0,590^{* *}$ & $\mathbf{1 , 0 0 0}^{*}$ \\
\hline${ }^{*}$ Açılklanan ortalama varyansin karekökü & ${ }^{* *}$ Faktörler arası korelasyonlar & & \\
\hline
\end{tabular}

Ayırt edici geçerlik, birbirleriyle ilgili teorik yapıların farklılaşması ve bu yapıların kendi arasındaki ilişkinin çok yüksek olup olmadığını belirlemektedir. Bir boyutu ölçen faktörlerin birbiriyle ilişkili, fakat birbiriyle aynı olmaması beklenir. Fornell ve Larcker (1981) kriteri gereği, ayırt edici geçerlik test edilirken, bir faktöre ilişkin açıklanan ortalama varyansın kare kökünün, diğer faktörlerle olan korelasyon katsayılarından yüksek olması gerekmektedir (Uşaklı ve Küçükergin, 2018). Ayırt edici geçerlik sonuçlarında, duygusal gastronomik imaj ve bilişsel/algısal gastronomik imaj algılarının birbiriyle ilişkisi yüksek çıkmış ve bu ilişkiyi yükselten "konya yemekleri rahatsızlık verir" maddesi duygusal gastronomik imaj ölçeğinden çıarılmıştır. Araştırmanın ölçüm modeline yönelik ayırt edici geçerlik analizi ve yapılar arasındaki korelasyon katsayıları Tablo 6'da yer almaktadır. Tablo 6'da belirtildiği üzere ölçülen boyutlar arasında hesaplanan açıklanan ortalama varyans karekök değerleri, söz konusu yapının diğer yapılarla olan korelasyon kat sayısından yüksektir. Ölçüm modelinin ayırt edici geçerliği sağladığı görülmektedir.

\section{İçsel model}

İçsel model bölümünde Hair vd., (2017) ve Uşaklı ve Küçükergin (2018)'in tavsiyeleri ile yapısal yol ilişkilerini belirlemeye yönelik test sonuçları verilmiştir. Buna göre modelin ilişki yolu değerlendirmesinde $\mathrm{R}^{2}, \mathrm{Q}^{2}, \beta, f^{2}$, $t$ ve $p$ değerleri belirtilmiştir. $\mathrm{R}^{2}$ değeri, bir içsel (etkilenen ya da bağımlı) değişkene ait varyansın açılanma yüzdesini belirtir. 0.75 , 0.50 veya 0.25 değerleri sırasıyla büyük, orta ve zayıf olarak değerlendirilir (Hair vd., 2017). Modelin değerlendirilmesinde $R^{2}$ değerlerine bakılmış (Bknz. Şekil 1) ve Hair vd., (2017)'nin yönlendirmeleri dikkate alınarak $R^{2}$ değerlerinin ortaya yakın ve kabul edilebilir düzeyde olduğu belirlenmiştir $\left(R^{2}>0.25\right)$. 
Dışsal (etkilenen ya da bağımsız) değişkenin içsel değişkene ait $\mathrm{R}^{2}$ değerine olan katkısını değerlendirmek için $f^{2}$ değerlerine bakılmaktadır (Hair vd., 2017). $f^{2}$ değerleri, 0.02 "küçük", 0.15 "orta" ve 0.35 "büyük" etki olarak yorumlanmaktadır (Cohen, 1988; Hair, 2017; Uşaklı ve Küçükergin, 2018). Araştırmanın $f^{2}$ değerleri Tablo $7^{\prime}$ de yer almaktadır. $f^{2}$ sonuçlarını orta etkiye yakın ve büyük etki şeklinde yorumlamak mümkündür.

Tablo 7'de araştırma modeli sonucu ortaya konmuş hipotez sonuçları, $\beta, f^{2}, t$ ve $p$ değerleri yer almaktadır. Standart beta ( $\beta$ ) katsayıları, bir değişkenin, bir başka değişken üzerindeki etkisinin büyüklügünü ifade etmektedir. Modelin etki büyüklüğü sınıflandırılması; $0.10^{\prime}$ dan küçük değer alan beta katsayılarını "az etki", 0.10-0.50 arasında değer alanları "orta etki", 0.50 üzerindeki beta katsayılarını ise "yüksek etki" olarak belirlenmiştir (Hair vd., 2017; Kline, 2011; Uşaklı ve Küçükergin, 2018; Uşaklı, 2016).

Tablo 7. İçsel model hipotez testi sonuçları

\begin{tabular}{|c|c|c|c|c|c|c|}
\hline Hipotez & Etki & Beta* & $t$ değeri & $p$ & Sonuç & $f^{* * *}$ \\
\hline $\mathrm{H}_{1}$ & $\begin{array}{c}\text { Duygusal Gastronomik İmaj } \\
\text { Bilişsel/Algisal Gastronomik İmaj }\end{array}$ & 0,680 & 16,603 & 0,000 & Kabul & 0,859 \\
\hline $\mathbf{H}_{2}$ & $\begin{array}{l}\text { Duygusal Gastronomik İmaj } \\
\text { Genel Gastronomik İmaj }\end{array}$ & 0,590 & 4,447 & 0,000 & Kabul & 0,102 \\
\hline $\mathbf{H}_{3}$ & $\begin{array}{c}\text { Bilişsel/Algisal Gastronomik İmaj } \\
\qquad \\
\text { Genel Gastronomik İmaj }\end{array}$ & 0,385 & 5,096 & 0,000 & Kabul & 0,140 \\
\hline $\mathbf{H}_{4}$ & $\begin{array}{l}\text { Genel Gastronomik İmaj } \\
\text { Genel Destinasyon İmaj }\end{array}$ & 0,561 & 13,738 & 0,000 & Kabul & 0,459 \\
\hline \multicolumn{7}{|c|}{$\begin{array}{l}\text { * } \beta<0,10 \text { “az", } \beta: 0,10-0,50 \text { arası "orta"; } \beta>0,50 \text { "yüksek" etki olarak sınıflandırılmıştır. } \\
\text { **0,02 küçük, } 0,15 \text { orta, } 0,35 \text { büyük etki olarak yorumlanmıştır. }\end{array}$} \\
\hline
\end{tabular}

Şekil 1 ve Tablo 7' de görüldüğü üzere bilişsel/algısal gastronomik imajın genel gastronomik imajı orta düzeyde etkilediği $\left(\beta=0,385, p=0,000 ; f^{2}=0,140\right)$, duygusal gastronomik imajın hem bilişsel/algısal gastronomik imajı $\left(\beta=0,680 ; p=0,000 ; f^{2}=0,859\right)$ hem de genel gastronomik imaj1 $\left(\beta=0,590 ; p=0,000 ; f^{2}=0,102\right)$ yüksek düzeyde etkilediği ve genel gastronomik imajın genel destinasyon imajını $\left(\beta=0,561 ; p=0,000 ; f^{2}=0,459\right)$ yüksek düzeyde etkilediği belirlenmiştir. 


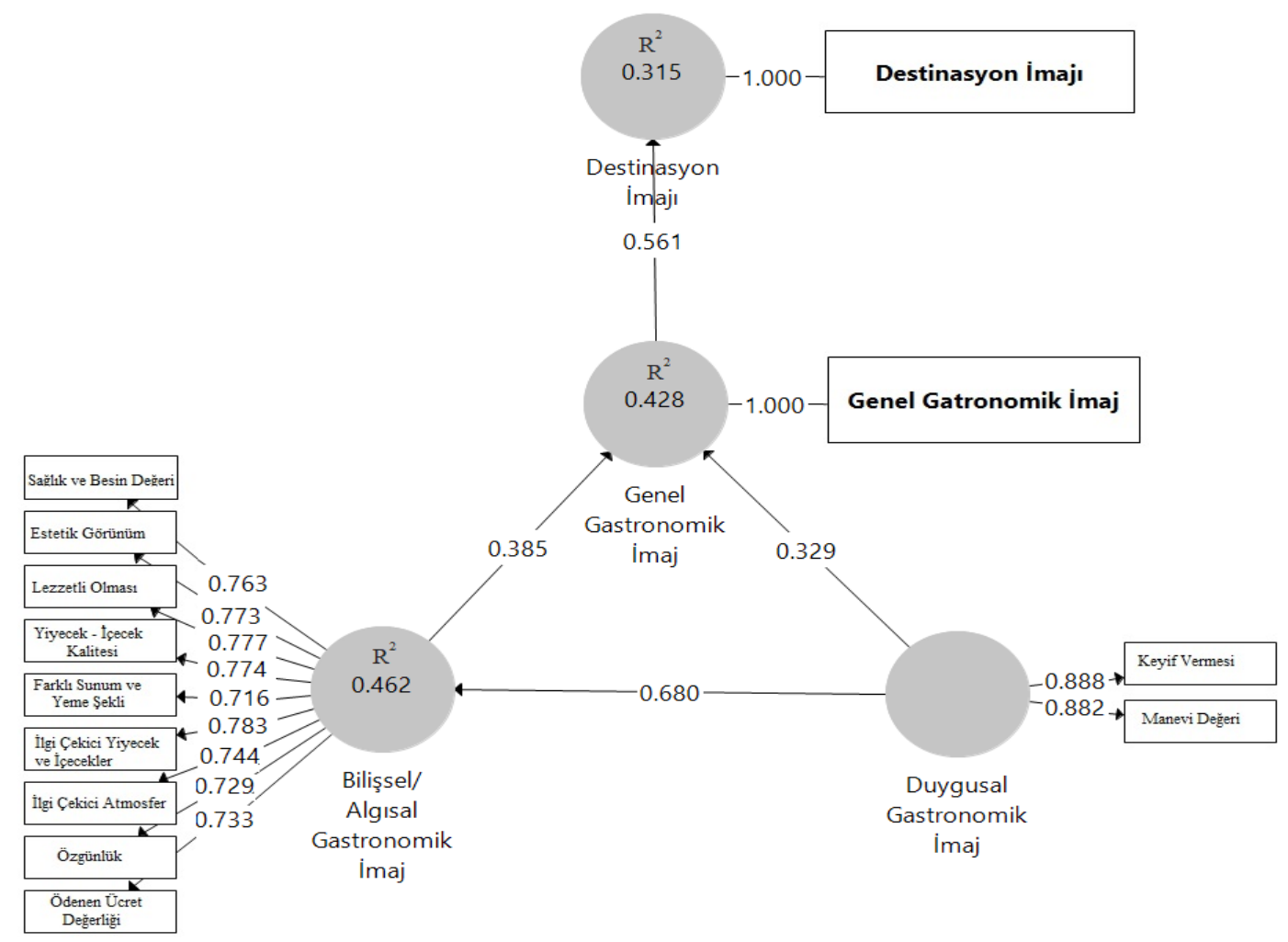

Not: Genel gastronomik imaj $\mathrm{Q}^{2}=0,413$; bilişsel/algısal gastronomik imaj $\mathrm{Q}^{2}=0,244$;

destinasyon imaj $1 \mathrm{Q}^{2}=0,305$

Şekil 1. Araştırma Modeli Sonucu

$\mathrm{Q}^{2}$ değeri, bir yapısal modelin tahmin etme uygunluğunu değerlendirmede kullanılır. $\mathrm{Q}^{2}$ değerinin $0^{\prime} 1$ aşması beklenir ve bu durum dışsal bir değişkenin ilgili içsel değişken için tahmin etme uygunluğuna sahip olduğuna işaret eder (Hair vd., 2017). Araştırmanın ölçüm modelinde yer alan genel gastronomik imaj, bilişsel/algısal gastronomik imaj ve destinasyon imajı $\mathrm{Q}^{2}$ değerlerine bakıldığında hepsi $0^{\prime}$ dan büyüktür ve değerlerin uygun olduğu belirlenmiştir (Bknz. Şekil 1).

Yapılan analiz sonuçlarına göre;

" $H_{5}$ : Konya'yı ziyaret eden turistlerin bilişsel/algısal gastronomik imaj algılarının genel gastronomi imaj algilar üzerinde olumlu etkisi vardır."

" $H_{6}:$ Konya'yı ziyaret eden turistlerin duygusal gastronomik imaj algılarının bilişsel/algısal gastronomi imaj algilar üzerinde olumlu etkisi vardır."

" $H_{7}$ : Konya'yı ziyaret eden turistlerin duygusal gastronomik imaj algılarmin genel gastronomi imaj algilar üzerinde olumlu etkisi vardır."

" $\mathrm{H}_{8}$ : Konya'yı ziyaret eden turistlerin genel gastronomik imaj algilarının genel destinasyon imaj alguları üzerinde olumlu etkisi vardır." hipotezleri kabul edilmiştir.

\section{SONUÇ VE ÖNERILER}

Bir destinasyona özgü gastronomik kimlik ve imaj, o destinasyonun taklit edilmesini zorlaştırmakta, güçlü bir marka unsuru olarak yer alabilmekte ve hatta destinasyonu ziyaret etme motivasyonu olabilmektedir. Destinasyon marka oluşumunda gastronomik kimlik ve imajın önemini ortaya koyan bu araştırmada, Konya'ya gelen turistlerin Konya gastronomik imaj 
algılarının, Konya genel destinasyon imaj algılarını etkileme düzeyi ve dolayısıyla destinasyon marka oluşumunda gastronomik imajın önemi ortaya konmuştur. Ayrıca araştırmada Konya ilinin gastronomik imaj unsurları belirlenmiştir.

Araştırmaya katılan turistlerin profili değerlendirildiğinde; erkek ve kadın oranın birbirine yakın olduğu, çoğunun orta yaşta olduğu, üniversite eğitimi alanların fazla olduğu, gelir açısından ise orta gelirde oldukları ve çoğunun İstanbul'da yaşadığı söylenebilir. Konya'nın gastronomik marka algısına verilen cevaplarda en yüksek yüzdelerin etliekmek ve bamya çorbasında olduğu tespit edilmiştir.

Araştırmada turistlerin bilişsel/algısal gastronomik imaj, duygusal gastronomik imaj, genel gastronomik imaj ve destinasyon imajı algılarının birbirlerini etkileme düzeyleri incelenmiştir. Yapısal eşitlik modellemesi ile yapılan analizler sonucunda ise genel gastronomik imajın destinasyon imajını yüksek düzeyde etkilediği, duygusal imajın bilişsel/algısal imajı ve genel gastronomik imajı yüksek düzeyde etkilediği, bilişsel/algısal gastronomik imajın da genel gastronomik imajı orta düzeyde etkilediği belirlenmiştir. Buna göre araştırma modelini oluşturan $\mathrm{H}_{1}, \mathrm{H}_{2}, \mathrm{H}_{3}, \mathrm{H}_{4}$ hipotezleri kabul edilmiştir.

Araştırmada duygusal gastronomik imajın, bilişsel/algısal imajı ve genel gastronomik imajı etkilediği sonucu çımıştır. Duygulardan etkilenen gastronomik imaj algısının bilişsel/algısal gastronomik imajı etkilemesi önemli bir sonuçtur. Öyle ki gastronomik imaj yaratılmasında duygusal gastronomik imajın dikkate alınması ve doğru bir gastronomik imaj oluşturulmasında dikkat edilmesi gerekmektedir. Diğer yandan araştırmada bilişsel/algısal ve duygusal gastronomik imajın genel gastronomik imaj algısını olumlu düzeyde etkilediği sonucu bulunmuştur. Turistlerin Konya gastronomisi ile ilgili düşünceleri ve duyguları genel gastronomik imaj etkilemekte ve dolaylı olarak destinasyon imajı algısına etki etmektedir. Bu açıdan bakıldığında gastronomik imaj algısının destinasyon markalamasında önemli olduğu görülmektedir. Gastronomik imajın, destinasyonun genel imaj algısına olan olumlu etkisi ile gastronominin önemli bir marka bileşeni ve etkileme gücü yüksek bir destinasyon çekicilik unsuru olduğu ortadadır.

Destinasyonların sahip olduğu kaynakların etkin bir şekilde kullanılması oldukça önemlidir. Konya gastronomisi, Konya şehri için özgün deneyimler sunma özelliklerine sahiptir. Pine ve Gilmore (2012) deneyimleri, ürün ve hizmetlerden farklı bir ekonomik sunu olarak ortaya koymuşlar ve yazarlara göre müşteriler bir ürünü ya da hizmeti sadece onlara sağladığ 1 faydalardan dolayı satın almamakta, o ürün ya da hizmetin hafızalarında bıraktıkları hoş deneyimlerle de ilgilenmektedirler bu nedenle de her bir müşteri için farklı, sıra dışı ve kişiselleştirilmiş deneyimlerin yaratılması gerekliliğini ifade etmişlerdir. Konya tarihsel geçmişi, coğrafi konumu, gelişmiş sosyal yapısı, coğrafi olanakları, inançlar etrafında şekillenen kültürünün gastronomiye yansıması ile benzersiz bir destinasyon markası sağlama olanağına sahiptir. Mevlâna Celâleddin Rumi, Konya'nın en önemli kişiliklerinden biridir ve mesafeleri aşmış bir üne sahiptir. Konya şehrinin destinasyon planlaması yapılırken, Konya mutfağının yanı sıra Mevlevi mutfak gelenekleri ve Selçuklu mutfak geleneklerine yönelik deneyim yaratma yolunda çalışmalar yapılmalıdır. Konya mutfağı özelliklerinin turistlere farklı deneyimler sunabilmesini sağlamaya yönelik çalışmaların yapılması Konya şehrinin tanıtılmasına ve olumlu imaj oluşturmaya da etki edecektir. Diğer yandan uluslararası tanınırlı̆̆ı olan bir diğer unsur Çatalhöyük'tür. Gastronomi açısından değerlendirildiğinde, Çatalhöyük gastronomik unsurlarının mutfak sanatlarıyla birleştirilerek Çatalhöyük teması etrafında şekillenen mutfak sunumu hem ülke gastronomisine hem de Konya'ya fayda sağlayacaktır.

Araştırma sonuçları göz önüne alınarak Konya gastronomisi ile ilgili öneriler aşağıda sıralanmiştır: 
$\checkmark$ Gastronomik kimlik ve imaj konusunda turizm paydaşlarının bilgilendirilmesi,

$\checkmark$ Konya gastronomisini tanıtan etkinliklerin yapılması (gastronomi festivalleri, seminerler, toplantılar vb.),

$\checkmark$ Coğrafi işaretli ürünler ile ilgili yerel yönetim ve halkın bilgilendirilmesi,

$\checkmark$ Aşçlık eğitimi alan öğrencilere yöresel mutfak hakkında bilgilendirmelerin yapılması,

$\checkmark$ Turist rehberlerine yönelik Konya mutfak kültürü ile ilgili eğitimlerin düzenlenmesi,

$\checkmark$ Konya gastronomisini araştıran enstitülerinin kurulması,

$\checkmark \quad$ Konya'ya özgü yiyecek ve içeceklerin satın alınabildiği gastronomi müzelerinin açılması (Çatalhöyük gastronomi müzesi, Ateşbaz-1 Veli gastronomi müzesi gibi.),

$\checkmark$ Turistlere yönelik aktif ya da pasif katılımlı gastronomik etkinliklerin düzenlenmesi (yöresel yemek kursları, yemek yarışmaları, gastronomik sergiler vb.),

$\checkmark$ Bölge gastronomisinin tanıtımında ulusal ve uluslararası medyanın aktif bir şekilde kullanılması,

$\checkmark$ Yenilebilir ve yenilemez gastronomik unsurların marka değer haline gelmesi ve turistik ürün olarak sunulmasıdır.

\section{KAYNAKÇA}

Acar, Y. (2018). Türkiye'deki coğrafi işaretli ürünlerin destinasyon markalaması kapsamında değerlendirilmesi. Journal of Tourism and Gastronomy Studies, 6 (2), 163-177.

Akdağ, G., Akgündüz, Y., Güler, O. ve Benli, S. (2015). Bir seyahat motivasyon aracı olarak gastronomi: Hatay'ı ziyaret eden yerli turistlerin seyahat motivasyonları, yiyecek-içecek deneyimleri ve seyahat memnuniyetleri üzerine bir araştırma. 1. Eurisia International Tourism Congress: Current Issues, Trends and Indicators, 28-30 Mayıs 2015, Konya

Akkor, Ö. (2014). Selçuklu Mutfağı. İstanbul: Alfa yayınevi

Aksoy M., Akbulut B. A. ve İflazoğlu N. (2016). Mevlevilikte mutfak kültürü ve Ateşbaz-ı Veli makamı, Journal of Tourism and Gastronomy Studies, 4 (1), 96-103.

Aksoy, M. ve Sezgi, G. (2015). Gastronomi turizmi ve Güneydoğu Anadolu Bölgesi gastronomik unsurları. Journal of Tourism and Gastronomy Studies, 3 (3), 79-89.

Akyol, C. (2018). Destinasyonların sahip olduğu gastronomi kimliğine bir bakış; Manisa örneği. Journal of Tourism and Gastronomy Studies, 6 (3), 240-249.

Alkış, N . (2016). Bayes yapısal eşitlik modellemesi: Kavramlar ve genel bakış. Gazi İktisat ve İşletme Dergisi, 2 (3), 105-116.

Apak, Ö. C. ve Gürbüz, A. (2018). Turistlerin yöresel gıda ürünlerine ilgi düzeyleri. Journal of Tourism and Gastronomy Studies, 6(2), 315-330.

Artuğer, S. ve Fidan, D. (2018). Restoranlardaki atmosferik unsurların müşteri memnuniyeti üzerine etkisi. Journal of Tourism and Gastronomy Studies, 6(4), 267

Aslan, Z., Güneren, E. ve Çoban, G. (2014). Destinasyon markalaşma sürecinde yöresel mutfağın rolü: Nevşehir örneği. Journal of Tourism and Gastronomy Studies, 2 (4), 3-13.

Aydoğdu, A., Özkaya Okay, E. ve Köse, Z. C. (2016). Destinasyon tercihinde gastronomi turizminin önemi: Bozcaada örneği. Uluslararası Türk Dünyası Turizm Araştırmaları Dergisi, 1(2), 13.

Baloglu, S. and McCleary, K. W. (1999). A model of destination image formation. Annals of Tourism Research, 26 (4), 868-897.

Baloğlu, S. (1997). The relationship between destination images and sociodemographic and trip characteristics of international travelers. Journal of Vacation Marketing, 3(3), 221-233.

Başaran, B. (2017). Gastronomi turizmi kapsaminda rize yöresel lezzetlerinin değerlendirilmesi, Journal of Tourism and Gastronomy Studies, 3(5), 135-149. 
Başarangil, İ. ve Tokatlı, C. (2018). Yavaş yemek: Şile yeryüzü pazarı ziyaretçilerinin memnuniyet düzeylerinin değerlendirilmesi üzerine bir araştırma, Journal of Tourism and Gastronomy Studies, 6(1), 3-19.

Batu, A. (2016). Kültür ve gastronomi bakımından Konya, The Journal of Academic Social Sciences, 30(30), 2038

Bayram, M. (2017). Tüketicilerin İstanbul restoranlarına yönelik algıları: memnuniyetlerini etkileyen unsurların değerlendirilmesi, Journal of Tourism and Gastronomy Studies, 5(4), 142-154.

Bayram, Ü. (2018). Gastronomik kültürel miras olarak Buldan Günbalı, Journal of Tourism and Gastronomy Studies, 6(1), 361-371.

Baysal, A., and Wright, K. I. (2005). Cooking, crafts and curation: ground-stone artefacts from Çatalhöyük. I. Hodder (Dü.) içinde, Changing Materialities at Catalhoyuk: reports from the 1995-1999 seasons (s. 307-324). Cambridge: University of Cambridge.

Beerli, A. and Martin, J. D. (2004). Factors influencing destination image. Annals of Tourism Research, 31 (3), 657-681.

Björk, P. and Kauppinen-Räisänen, H. (2014). Current issues in tourism exploring the multi-dimensionality of travellers' culinary-gastronomic experiences. Current Issues in Tourism, 19(12), 1260-1280.

Büyükşalvarcı A., Şapcılar M. C. ve Yılmaz G. (2016). Yöresel yemeklerin turizm işletmelerinde kullanılma durumu: Konya örneği, Journal of Tourism and Gastronomy Studies 4 (4), 165-181.

Chang, R. C. Y. and Mak, A. H. N. (2018). Understanding gastronomic image from tourists' perspective: A repertory grid approach, Tourism Management, 68, 89-100.

Correia, A., Moital, M., Da Costa, C. F. and Peres, R. (2008). The determinants of gastronomic tourists' satisfaction: a second-order factor analysis: Determinants of gastronomic tourists' satisfaction, Journal of Foodservice, 19(3), 164-176.

Cömert, M. (2014). Turizm Pazarlamasında yöresel mutfakların önemi ve Hatay mutfağı örneği. Journal of Tourism and Gastronomy Studies, 2(1), 64-70.

Çalışkan, O. (2013). Destinasyon rekabetçiliği ve seyahat motivasyonu bakımından gastronomik kimlik. Journal of Tourism and Gastronomy Studies, 1(2), 39-51.

Çapar, G. ve Yenipınar, U. (2016). Somut olmayan kültürel miras kaynağı olarak yöresel yiyeceklerin turizm endüstrisinde kullanılması. Journal of Tourism and Gastronomy Studies, 4(Special 1), 100-115.

Çavuş, O. ve Cömert, M. (2016). Moleküler gastronomi kavramı. Journal of Tourism and Gastronomy Studies, $4(4), 118-128$.

Diţoiu, M.C. and Căruntu, A.L. (2014). Sensory experiences regarding five-dimensional brand destination. Procedia - Social and Behavioral Sciences, 109, 301-306.

Durlu Özkaya, F., Sünnetçioğlu, S. ve Can, A. (2013). Sürdürülebilir gastronomi turizmi hareketliliğinde coğrafi işaretlemenin rolü, Journal of Tourism and Gastronomy Studies, 1(1), 13-20.

Dünya Turizm Örgütü. (2017). 3rd UNWTO World Forum on Gastronomy Tourism. İspanya: UNWTO. http://cf.cdn.unwto.org adresinden alındı

Eren, R. (2016). Türkiye'nin Gastronomi İmajı, Ziyaretçilerin Bilgi Kaynakları ve Harcamaları. Yayınlanmamış Doktora Tezi, Gazi Üniversitesi, Eğitim Bilimleri Enstitüsü, Ankara

Erkmen, E. (2018). Yerel mutfak deneyiminin tüketici temelli destinasyon marka denkliğine etkisi. Journal of Tourism and Gastronomy Studies, 6(2), 143-162.

Eroğlu, S. (2018). Turizmde Destinasyon Markalaşması: Niğde Üzerine Bir Uygulama. Yayımlanmamış Yüksek Lisans Tezi, Nevşehir Hacı Bektaş Veli Üniversitesi, Sosyal Bilimler Enstitüsü, Nevşehir.

Everett, S. and Aitchison, C. (2008). The role of food tourism in sustaining regional identity: a case study of Cornwall, South West England. Journal of Sustainable Tourism, 16(2), 150-167. 
Fox, R. (2007). Reinventing the gastronomic identity of Croatian tourist destinations, International Journal of Hospitality Management, 26(3), 546-559.

Frochot, I. (2003). An analysis of regional positioning and its associated food images in French tourism regional brochures, Journal of Travel and Tourism Marketing, 14(3-4), 77-96.

Gehrels, S. A. and Kristanto, S. (2007). Marketing of Dutch culinary restaurants: An exploration from the entrepreneur's perspective, Journal of Culinary Science and Technology, 5(2-3), 23-37.

Gordin, V. and Trabskaya, J. (2013). The role of gastronomic brands in tourist destination promotion: The case of St. Petersburg, Place Branding and Public Diplomacy, 9(3), 189-201.

Gunders, J. (2008). Professionalism, place, and authenticity in The Cook and the Chef, Emotion, Space and Society, 1(2), 119-126.

Güzel Şahin, G. ve Ünver, G. (2015). "Destinasyon pazarlama aracı olarak “gastronomi turizmi”: İstanbul'un gastronomi turizmi potansiyeli üzerine bir araştırma". Journal of Tourism and Gastronomy Studies, 3(2), 63-73.

Ha, J. and Jang, S. (Shawn). (2010). Effects of service quality and food quality: The moderating role of atmospherics in an ethnic restaurant segment, International Journal of Hospitality Management, 29(3), 520-529.

Hair J.F., Hult G.T.M., Ringle C. and Sarstedt, M. (2017). A Primer on Partial Least Squares Structural Equation Modeling (PLS-SEM). California: SAGE Publications.

Halıcı, N. (2015). Selçuklu Dönemi Mutfağı. Konya: Selçuklu Belediyesi Yayınları.

Harrington, R. J. (2005). Defining gastronomic identity, Journal of Culinary Science and Technology, 4(2-3), 129152.

Harrington, R. J. and Ottenbacher, M. C. (2010). Culinary tourism-a case study of the gastronomic capital, Journal of Culinary Scienceand Technology, 8(1), 14-32.

Hjalager, A. M. and Corigliano, M. A. (2000). Food for tourists-determinants of an image, The International Journal of Tourism Research, 2(4), 281-294

Horng, J. S. and (Simon) Tsai, C.T. (2010). Government websites for promoting East Asian culinary tourism: A cross-national analysis, Tourism Management, 31(1), 74-85.

Hoşcan, N., Genç, K. ve Şengül, S. (2016). Bolu kent markası oluşturma sürecinde aşçllık kültürü ve gastronomi turizminin önemi: Bolgamer önerisi, Journal of Tourism and Gastronomy Studies 4(1), 52-76.

İlban, M. O., Bezirgan, M. ve Çolakoğlu, F. F. (2018). Destinasyon bağlılığ1 yaratmada gastronomi marka imajı ve gastronomi aşinalığının rolü: Kemer örneği, Journal of Tourism and Gastronomy Studies, 6(2), 622-640.

Karim, S. (2006). Culinary Tourism As A Destination Attraction: An Empirical Examination Of The Destination's Food Image And Information Sources. Yayınlanmamıș Doktora Tezi, Oklahoma State University, ABD.

Kivela, J. J. and Crotts, J. C. (2009). Understanding travelers' experiences of gastronomy through etymology and narration, Journal of Hospitality and Tourism Research, 33(2), 161-192.

Kılıçhan, R. ve Köşker, H. (2015). Destinasyon markalaşmasında gastronominin önemi: Van kahvaltısı örneği, Journal of Tourism and Gastronomy Studies, 3(3), 102-115.

Kızılırmak, İ., Ofluoğlu, M. ve Şişik, L. (2016). Türkiye de uygulanan gastronomi turları rotalarının web tabanlı analizi ve değerlendirmesi, Journal of Tourism and Gastronomy Studies, 4(Special 1), 258-258.

Küçükkömürler, S., Şirvan, N. B. ve Sezgin, A. C. (2018). Dünyada ve Türkiye'de gastronomi turizmi, Uluslararası Turizm, Issletme, Ekonomi Dergisi, 2(2), 78-85.

Lee, A. H. J., Wall, G. and Kovacs, J. F. (2015). Creative food clusters and rural development through place branding: Culinary tourism initiatives in Stratford and Muskoka, Ontario, Canada, Journal of Rural Studies, $39,133-144$.

Lin, Y. C., Pearson, T. E. and Cai, L. A. (2011). Food as a form of destination identity: A tourism destination brand perspective, Tourism and Hospitality Research, 11(1), 30-48. 
Lopez-Guzman, T., Hernandez-Mogollon, J. M. and Di Clemente, E. (2014). Gastronomic tourism as an engine for local and regional development, Regional and Sectoral Economic Studies, 14(1), 95-102.

Lopez-Guzman, T. and Sanchez-Canizares, S. (2012). Gastronomy, tourism and destination differentiation: A case study in Spain. Rev Econ Finance, 1, 63-72.

Lu, A. C. C., Gursoy, D. and Lu, C. Y. (2015). Authenticity perceptions, brand equity and brand choice intention: The case of ethnic restaurants. International Journal of Hospitality Management, 50, 36-45.

MacKay, K. and Fesenmaier, D. (1997). Pictorial element of destination in image formation, Annals of Tourism Research 24 (2),537-565

Mankan, E. (2017). Destinasyon pazarlamasında çekici bir faktör olarak Türkiye'deki gastronomi müzeleleri, Journal of Turkish Studies, 12(4), 641-654.

Martínez-Monzó, J., García-Segovia, P. and Albors-Garrigos, J. (2013). Trends and innovations in bread, bakery and pastry, Journal of Culinary Science and Technology, 11(1), 56-65.

Nam, J. H. and Lee, T. J. (2011). Foreign travelers' satisfaction with traditional Korean restaurants, International Journal of Hospitality Management, 30(4), 982-989.

Nilsson, J. H., Svärd, A. C., Widarsson, Å. and Wirell, T. (2011). 'Cittáslow' eco-gastronomic heritage as a tool for destination development, Current Issues in Tourism, 14(4), 373-386.

Okumus, B., Okumus, F. and McKercher, B. (2007). "Incorporating local and international cuisines in the marketing of tourism destinations: The cases of Hong Kong and Turkey". Tourism Management, 28(1), 253261.

Orhan, A. (2010). Yerel değerlerin turizm ürününe dönüştürülmesinde "coğrafi işaretlerin" kullanımı: İzmit Pişmaniyesi örneği, Anatolia: Turizm Araştırmaları Dergisi, 21(2), 243-254.

Ottenbacher, M. and Harrington, R. J. (2007). The culinary innovation process: a study of Michelin-Starred Chefs, Journal of Culinary Science and Technology, 5(4), 9-35.

Özkan, Ç. ve Aydın, Ş. (2018). Yerel yiyecekler aracılığı ile sürdürülebilir destinasyonlar: Ayvacık örneği, Journal of Tourism and Gastronomy Studies, 6(1), 335-349.

Pine, J. ve Gilmore, J. (2012). Deneyim Ekonomisi. İstanbul: Optimist Yayınları.

Quan, S. and Wang, N. (2004). Towards a structural model of the tourist experience: An illustration from food experiences in tourism, Tourism Management, 25(3), 297-305.

Ramli, A. M., Zahari, M. S. M., Halim, N. A. and Aris, M. H. M. (2016). The Knowledge of food heritage identithy in Klang Valley, Malaysia. Procedia - Social and Behavioral Sciences, 222, 518-527.

Robinson, R. N. S. and Clifford, C. (2012). Authenticity and festival foodservice experiences, Annals of Tourism Research, 39(2), 571-600.

Sandıkçı, M. ve Töre Başat, H. (2017). Gastronomik kimlik oluşturmada yöresel ürünlerin rolü: Ürünlerin satış ve pazarlanmasına yönelik bir örnek olay incelemesi, Journal of Tourism and Gastronomy Studies, 5(2), $64-76$.

Sarışık, M. ve Özbay, G. (2015). Gastronomi turizmi üzerine bir literatür incelemesi, Anatolia Turizm Araştırmaları Dergisi, 26(2), 264-278.

Schulp, J. A. and Tirali, I. (2008). Studies in immigrant restaurants : Culinary concepts of Turkish restaurants in the Netherlands, Journal of Culinary Science and Technology, 6(2-3), 119-150.

Seçim, Y. (2018). Yöresel bir ürün olan Konya Etliekmeği ve genel özellikleri hakkında nitel bir çalışma, Journal of Tourism and Gastronomy Studies, 6(4), 197-209. doi:10.21325/jotags.2018.304

Serçek, S. (2018). Turistlerin yerel yemek tüketimindeki motivasyon faktörlerinin incelenmesi, Journal of Tourism and Gastronomy Studies, 6(4), 463-481.

Serçeoğlu, N. (2014). Yöre halkının mutfak kültürünü tanıma durumunun tespit edilmesi: Erzurum ili 
örneği, Journal of Tourism and Gastronomy Studies, 2(4), 36-46.

Seyitoğlu, F. ve Çalışkan, O. (2014). Turizm literatüründe Türk Mutfağı üzerine yapılan araştırmaların değerlendirilmesi, Journal of Tourism and Gastronomy Studies, 2(4), 23-35.

Sidali, K. L., Kastenholz, E. and Bianchi, R. (2015). Food tourism, niche markets and products in rural tourism: combining the intimacy model and the experience economy as a rural development strategy, Journal of Sustainable Tourism, 23(8-9), 1179-1197.

Sims, R. (2009). Food, place and authenticity: local food and the sustainable tourism experience, Journal of Sustainable Tourism, 17(3), 321-336.

Sormaz, Ü. ve Güneş, E. (2016). Traditional culinary museums : samples from Turkey, International Journal of Humanities and Social Science Invention, 5(6), 27-31.

Suna, B. ve Uçuk, C. (2018). Coğrafi işaret ile tescil edilmiş ürüne sahip olmanın destinasyon pazarlamasına etkisi, Journal of Tourism and Gastronomy Studies, 6(3), 100-118.

Şahbaz, R. P. ve Kılıçlar, A. (2009). Filmlerin ve televizyon dizilerinin destinasyon imajına etkileri, İşletme Araştırmaları Dergisi, 1 (1), 31-52

Şen, A. ve Aktaş, N. (2017). Tüketicilerin seyahatleri sırasında besin seçimleri, yöresel gastronomi davranışları ve destinasyon seçiminde gastronomi unsurlarının rolü: Konya-Karaman örneği, KMÜ Sosyal ve Ekonomik Araştırmalar Dergisi, 19(32), 65-72.

Şengül, S. (2018). Destinasyon gastronomi marka değeri bileşenlerinin seyahat niyeti üzerine etkisi (Bolu örneği), Abant Izzet Baysal Üniversitesi Sosyal Bilimler Enstitüsü Dergisi, 18(1), 1-22.

Taştan, H. ve İflazoğlu, N. (2018). Hatay'ın Unesco gastronomi şehri olması ile ilgili yerel restoran işletmelerinin farkındalığının değerlendirilmesi, Journal of Tourism and Gastronomy Studies, 6(3), 384-393.

Telbakan, M. (2017). Yöresel yemeklerin bölge turizmine katkısı: Samsun kaz tiridi örneği, Journal of Tourism and Gastronomy Studies, 5(4), 155-169.

Teyin, G., Aslan, N., Sormaz, Ü., Pekerşen, Y. ve Nizamlıŏlu, H. F. (2017). Turizm sektöründe etnik restoranlar: İstanbul örneği, Journal of Tourism and Gastronomy Studies, 5(2), 77-87.

Toksöz, D. ve Aras, S. (2016). Turistlerin seyahat motivasyonlarında yöresel mutfağın rolü, Journal of Tourism and Gastronomy Studies, 4(Special 1), 174-174.

Tüfekçi, Ö. K., Kalkan, G. ve Tüfekçi, N. (2016). Eğirdir destinasyonunun marka kimlik unsurlarının incelenmesi: Gastronomi kimliğine yönelik bir çalışma, Journal of Tourism and Gastronomy Studies, 4(Special 1), 200-214

TÜRSAB (2014). Dünya Gastronomi Turizmi Raporu. Ankara: Türkiye Seyahat Acentaları Birliği. https://www.tursab.org.tr adresinden alındı [Erişim Tarihi: 10.11.2017]

Türk Dil Kurumu. (2018). Türkçe Sözlük, www.tdk.gov.tr. adresinden alındı [Erişim Tarihi: 10.10.2017].

Uşaklı A. and Küçükergin G. (2018). Using partial least squares structural equation modeling in hospitality and tourism- Do researchers follow practical guidelines? International Journal of Contemporary Hospitality Management, 30 (11), 3462-3512.

Westering, J. (1999). Heritage and gastronomy: The pursuits of the 'new tourist', International Journal of Heritage Studies, 5(2), 75-81.

Williams, H. A., Williams Jr, R. L. and Omar, M. (2014). Gastro-tourism as destination branding in emerging markets, International Journal of Leisure and Tourism Marketing, 4(1), 1-18.

Yamane, T. (2001). Temel Örnekleme Yöntemleri. A. Esin, M. A. Bakır, C. Aydın ve E. Gürbüzsel (çev.). İstanbul: Literatür Yayıncıllk

Yavuz, M. C. (2007). Uluslararası Destinasyon Markası Oluşturulmasında Kimlik Geliştirme Süreci: Adana Örneği. Yayınlanmamış Doktora Tezi, Çukurova Üniversitesi, Sosyal Bilimler Enstitüsü, İşletme Anabilim Dalı, Adana. 
Yazıcıŏ̆lu, İ. ve Akbulut, B. A. (2018). Türkiye'de Aşure Geleneği ve Gastronomi Turizmi Potansiyelinin Değerlendirilmesi, 2. Uluslararası Turizmin Geleceği; İnovasyon, Girişimcilik ve Sürdürebilirlik Kongresi, Mersin, 27-30 Eylül 2018.

Yazıcıoğlu, İ., Yaylı, A., Şahbaz, R. P. ve Yüksel, S. (2017). Cuisine in destination marketing: How delicious is your destination? Journal of Tourism and Gastronomy Studies, 5, 360-382.

Yenipınar, U., Köşker, H. ve Karacaoğlu, S. (2014). Turizmde yerel yiyeceklerin önemi ve coğrafi işaretleme: Van otlu peyniri. Journal of Tourism and Gastronomy Studies, 2(2), 13-23.

Yıldırım Saçılık, M., Çevik, S. ve Toptaş, A. (2018). Geçmişin mutfağından gelecekteki sofralara: BandırmaErdek yöresinin gastronomik mirası, Journal of Tourism and Gastronomy Studies, 6(1), 300-319.

Yılmaz, G. (2017). Gastronomi ve turizm ilişkisi üzerine bir değerlendirme, Journal of Travel and Hospitality Management 14(2), 171-191.

Yüksel, A. and Yüksel, F. (2003). Measurement of tourist satisfaction with restaurant services: A segmentbased approach, Journal of vacation marketing, 9(1), 52-68. 